\title{
"A Study to assess Practice of Housekeeping Staff Regarding Hazards of Biomedical waste Management"
}

\author{
Rekha Sharma ${ }^{1}$, Rajesh Kumar Sharma ${ }^{2}$, Shipra Dhimir ${ }^{3}$ \\ 1. MHA Student, Sai Institute of Paramedical \& Allied Sciences, Dehradun (UK) \\ 2. Associate Professor, Himalayan College of Nursing, SRHU, Dehradun (UK) \\ 3. Associate Professor, Sai Institute of Paramedical \& Allied Sciences, Dehradun (UK)
}

Corresponding E-mail : rajeshsharma.hon@gmail.com

\begin{abstract}
Introduction:-Issues of improving the management of bio-medical wastes are receiving attention throughout the world since healthcare institutions generate tons of biomedical waste each year. The key to minimization and effective management of biomedical waste is segregation (separation) and identification of the waste. Improper segregation leads to mixing of hazardous and non-hazardous waste and dumping of hazardous waste outside the hospital. This is a hazard to sanitary staff \& community as it can lead to many infectious diseases such as hepatitis, tetanus and HIV. The rag pickers who pick up discarded materials from such areas often use contaminated needles and sharp objects causing infection. So it is necessary to properly segregate the bio-medical waste at the point of generation only.

Method:- A research survey was carried out with quantitative research approach in CMI hospital. The purpose of the study was to assess the practice of housekeeping staff regarding hazards of biomedical waste management. Thirty samples were selected by convenient sampling technique. Practice was assessed by using self-reported practice check list.

Result:-Result shows that 25 (83.3) housekeeping staff had good practice about the hazards of biomedical management. Only Five housekeeping staff had average practice regarding biomedical managements.

Conclusion:-Study conclude that the selected variable such as age, gender, educational status, history of disease conditions, training of biomedical waste management and history of needle stick injuries had no statistically no significant association with the practice score of housekeeping staff except Job experience regarding biomedical waste management.
\end{abstract}

Key Word: Biomedical waste management, Hazards, Practice, housekeeping staff.

\section{INTRODUCTION}

Hospital is one of the complex institutions which has frequented by people from every walk of life in the society without any distinction between age, sex, race and religion. This is over and above the normal inhabitants of hospital i.e patients and staff. All of them produce waste which is increasing in its amount and type due to advances in scientific knowledge and is creating its impact. The hospital waste, in addition to the risk for patients and personnel who handle these wastes poses a threat to public health and environment. ${ }^{1}$

Contaminated sharps create greatest physical injuries and risk for infection. Mainly housekeeping staff at risk, because they are directly involved in handling process of waste that is during collection, transportation, compacting, grinding or shredding process, during the treatment of bio-medical waste. ${ }^{2}$

In accordance with these Rules (Rule 4), it is the duty of every "occupier" i.e a person who has the control over the institution and or its premises, to take all steps to ensure that waste generated is handled without any adverse effect to human health and environment. The hospitals, nursing homes, clinic, dispensary, animal house, pathological lab etc., are therefore required to set in place the biological waste treatment facilities. ${ }^{3}$

Waste should be collected and segregated according to the color code policy, should be stored at a common site, special vehicle should be there for its transportation and before disposal treatment should be given to the waste like incineration, autoclaving and shredding. ${ }^{4}$

Only $10-15 \%$ of hospital waste i.e. "Biomedical waste" is hazardous. But when hazardous waste is not segregated at the source of generation and mixed with non-hazardous waste, then $100 \%$ waste becomes hazardous. Hence, improper bio-medical waste segregation at source is risk to healthcare workers, waste handlers and the community. The objective of the project is to check out the practice regarding bio-medical segregation \& management at source. ${ }^{5}$

Adequate knowledge \& good practice about the bio-medical waste and its hazards can protect the housekeeping staff and community from various adverse effects of the hazardous waste. 


\section{METHODOLOGY}

A research survey was carried out with quantitative research approach in CMI hospital. The purpose of the study was to assess the practice of housekeeping staff regarding hazards of biomedical waste management. Thirty (30) samples (housekeeping staffs)who were dealing and handling biomedical waste in selected hospital, selected by convenient sampling technique. Practice was assessed by using self-reported practice check list.

\section{Data collection Procedure}

After approval from Head of Department, Hospital Administration, Sai Institute of Paramedical \& allied Sciences, Dehradun \& Permission from Chief Medical Superintendent of CMI hospital was obtained before data collection process. Before data collection, purpose of the study was explained to the participants and informed consent was obtained, then tool was administered to participants and confidentiality was maintained.

\section{RESULT AND ANALYSIS}

Table No.1 Characteristics of samples $(\mathrm{N}=30)$

\begin{tabular}{|l|l|l|}
\hline Variable & Freq & \% \\
\hline Age & & \\
18-35 years & 14 & 46.7 \\
36-55 years & 16 & 53.3 \\
\hline Gender & & \\
Male & 11 & 36.7 \\
Female & 19 & 63.3 \\
\hline Job Experience & & \\
Below 5 Year & 13 & 43.3 \\
Above 6 Years & 17 & 56.7 \\
\hline Educational Status & & \\
Less than 5 standard & 2 & 6.7 \\
6-10 standard & 16 & 53.3 \\
11-12 standard & 10 & 33.3 \\
Collegiate education & 2 & 6.7 \\
\hline History of disease & & \\
and infection & & \\
Yes & 2 & 6.7 \\
No & 28 & 93.3 \\
\hline
\end{tabular}

\begin{tabular}{|l|l|l|}
\hline Training of Biomedical & & \\
waste Management & & \\
Yes & 23 & 76.7 \\
No & 7 & 23.3 \\
\hline History of Needle & & \\
stick injury & 4 & 13.3 \\
Yes & 26 & 86.7 \\
No & & \\
\hline
\end{tabular}

Data presented in the table no 1 Shows that majority of housekeeping staff $16(53.3 \%)$ were from age group of 36-55 years. Most of the house keeping staff were female 19(63.3\%), Seventeen housekeeping staff were having above 6 years of experience of job regarding biomedical waste management. Majority 16 $(53.3 \%)$ were having $6-10^{\text {th }}$ standard education. Only 2 $(6.7 \%)$ had the history of disease and infection regarding biomedical waste management. Majority 23 $(76.7 \%)$ had training regarding biomedical waste management. Only $4(13.3 \%)$ had the history of Needle stick injury.

\section{History of disease \& Infection}

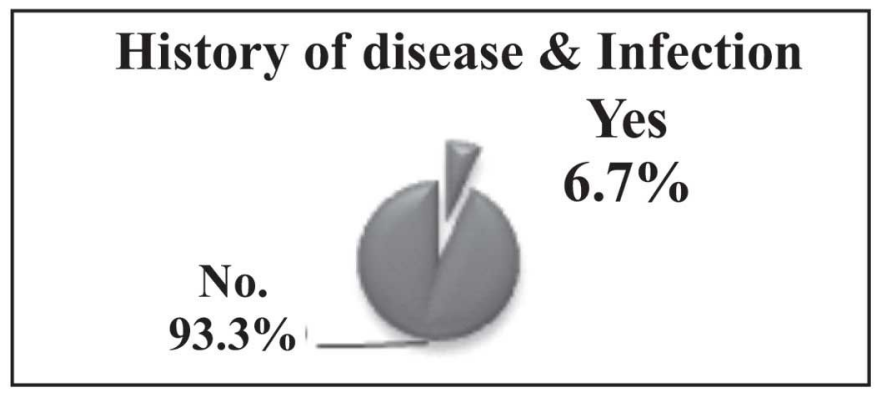

Fig: 1 Percentage distributions of samples according to History of disease \& Infection.

The data presented in figure showed that among 30 samples $2(6.7 \%)$ had history of disease \& infection rest of $28(93.3 \%)$ were not having any history of disease \& infection related to biomedical hazards.

Training of Biomedical waste management

Training of Biomedical waste management

$\square$ Yes $\square$ No

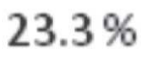

$76.7 \%$ 
Fig : 2Percentage distributions of samples according to Training of Biomedical waste management.

The data presented in figure showed that among 30 samples $23(76.7 \%)$ had Training of Biomedical waste management, rest of $7(23.3 \%)$ did not have any Training of Biomedical waste management.

\section{History of needle stick Injury}

\section{History of needle stick Injury}

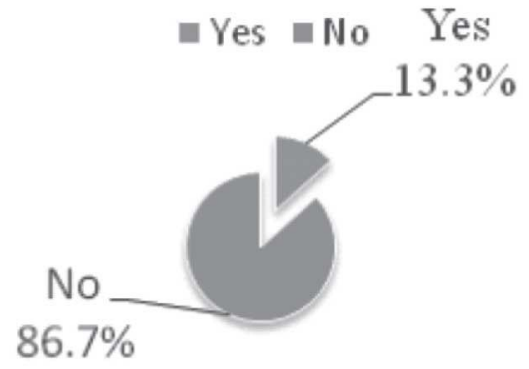

Fig: 3Percentage distributions of samples according to History of needle stick Injury.

The data presented in figure showed that among 30 samples $26(86.7 \%)$ had History of needle stick Injury, rest of $4(13.3 \%)$ did not have any History of needle stick Injury during biomedical waste management.

2. Practice score regarding Hazards of Biomedical Waste

Table No.2 Practice score regarding hazards of Biomedical Waste $(\mathrm{N}=30)$

\begin{tabular}{|l|l|l|}
\hline Practice Score & Range & Frequency \\
\hline Good & $17-24$ & 25 \\
\hline Average & $9-16$ & 5 \\
\hline Poor & $0-8$ & - \\
\hline
\end{tabular}

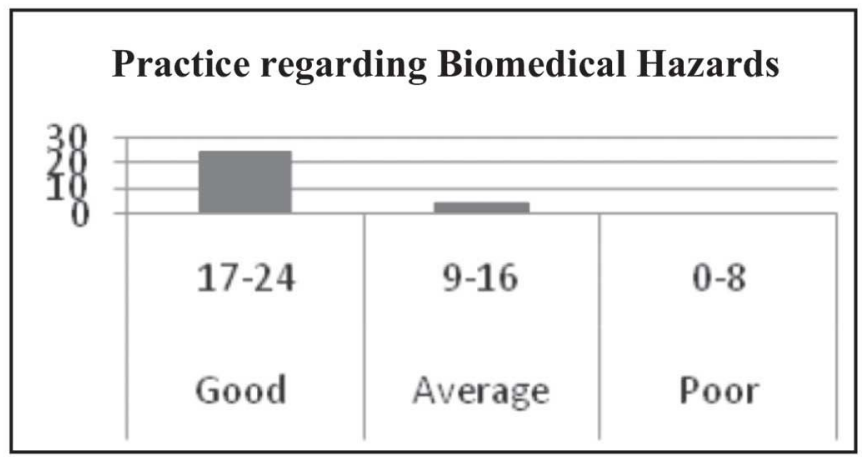

Figure No 4 shows frequency and percentage distribution of Practice score categories.

Practice score arbitrarily were divided in to three categories, good, average and poor knowledge. Data presented in table no 2 \& Figure No 8 depicts that most of the housekeeping staff $25(\%)$ had good practice about biomedical waste management and $5(\%)$ had average practice regarding biomedical hazards.

\section{Association between socio-demographic data and} Practice score

Table No 3.Association between baseline data and Practice score $(\mathrm{N}=30)$

\begin{tabular}{|c|c|c|c|}
\hline Variable & $\begin{array}{l}\text { At } \\
\text { Above } \\
\text { median } \\
(=21)\end{array}$ & $\begin{array}{l}\text { Below } \\
\text { Median } \\
(<21)\end{array}$ & $\begin{array}{l}P \\
\text { value }\end{array}$ \\
\hline $\begin{array}{l}\text { Age } \\
18-35 \text { years } \\
36-55 \text { years } \\
\end{array}$ & $\begin{array}{l}8 \\
9\end{array}$ & & .743 \\
\hline $\begin{array}{l}\text { Gender } \\
\text { Male } \\
\text { Female }\end{array}$ & $\begin{array}{l}6 \\
15\end{array}$ & $\begin{array}{l}5 \\
4\end{array}$ & .225 \\
\hline $\begin{array}{l}\text { Job Experience } \\
\text { Below } 5 \text { Year } \\
\text { Above } 6 \text { Years }\end{array}$ & $\begin{array}{l}13 \\
8\end{array}$ & $\begin{array}{l}0 \\
9\end{array}$ & .003 \\
\hline $\begin{array}{l}\text { Educational Status } \\
\text { Less than } 5 \text { standard } \\
6-10 \text { standard } \\
11-12 \text { standard } \\
\text { Collegiate education }\end{array}$ & $\begin{array}{l}0 \\
11 \\
8 \\
2\end{array}$ & $\begin{array}{l}2 \\
5 \\
2 \\
0\end{array}$ & .142 \\
\hline $\begin{array}{l}\text { History of disease } \\
\text { and infection } \\
\text { Yes } \\
\text { No }\end{array}$ & $\begin{array}{l}0 \\
21\end{array}$ & $\begin{array}{l}2 \\
7\end{array}$ & .083 \\
\hline $\begin{array}{l}\text { Training of } \\
\text { Biomedical waste } \\
\text { Management } \\
\text { Yes } \\
\text { No }\end{array}$ & $\begin{array}{l}16 \\
5\end{array}$ & $\begin{array}{l}7 \\
2\end{array}$ & 1.000 \\
\hline $\begin{array}{l}\text { History of Needle } \\
\text { stick injury } \\
\text { Yes } \\
\text { No }\end{array}$ & $\begin{array}{l}4 \\
17\end{array}$ & $\begin{array}{l}0 \\
9\end{array}$ & .287 \\
\hline
\end{tabular}


Data presented in table no 3 Shows statistically that only Job experience has statistically significance at the level of $0.003(\mathrm{p}<0.005)$, regarding biomedical waste management. There was no significance between practice score \& socio-demographic baseline data of sample such as age, gender, job experience, educational status, history of disease \& infection, training of biomedical waste management and history of needle stick injury. Chi-square was computed to find association between practice and baseline data.

\section{CONCLUSIONS}

The purpose of the study was to assess the practice of housekeeping staff regarding hazards of biomedical waste management. Based on the findings of the study following conclusion were drawn. Result of the study shows that only very few of the housekeeping staff, 2(6.7\%) had the history of disease and infection. Majority of the housekeeping staff, 23 $(76.7 \%)$ had the training of biomedical waste management. Majority of the housekeeping staff, 26 $(86.7 \%)$ had the history of needle stick injury. Majority 25 (83.3) housekeeping staff had good practice about the hazards of biomedical management. Only Five housekeeping staff had average practice regarding biomedical managements.

Study conclude that the selected variable such as age, gender, educational status, history of disease conditions, training of biomedical waste management and history of needle stick injuries had no statistically no significant association with the practice score of housekeeping staff except Job experience regarding biomedical waste management

\section{ACKNOWLEDGEMENTS:}

I would like to express my deep appreciation to Dr. Subhra Gupta, Medical Superintendent, CMI, Hospital, for granting necessary permission and constantly encouraging throughout the research project. In addition, I would like to express my gratitude to the Housekeeping staff of CMI Hospital (My Study Samples) for their full cooperation to make this study possible.

Sources of support: None

Conflict of interest: None

Declared Source of support in form of grants: None

\section{REFERENCES}

1. Hazards of biomedical waste management available at www.cwejowrnal.org/vol-7

2. Veda Hegde, RD Kulkarni, GS Ajantha, Biomedical waste management, Journal of Oral \& maxillofacial pathology, 2007, Vol 11, issue 1 Page no 5-9

3. Patil AD, Shekar AV, Health care management in India. J Environ manage. 2001;62:211-20

4. Radha KV, Kalavanik, Lavanya R. A case study of biomedical waste management in Hospitals, Global Journal of health sciences 2009;1:8288.

5. Saini S., Nagarjan, and Sharma RK. A study to assess Knowledge, attitude and practice among health care workers of a tertiary level hospital in Delhi avilabe at http//wwww.ijem.org.in/article.asp?issn=0970

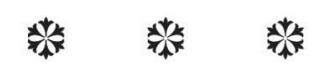

